\title{
Stability and Plasticity of Collection Samples of Durum Spring Wheat in the Forest-Steppe Conditions of Ukraine
}

\author{
Oleksandr Demydov ${ }^{1}$, Svitlana Khomenko ${ }^{1}$, Maryna Fedorenko ${ }^{1}$, Yevhenii Kuzmenko ${ }^{1}$, \\ Serhii Pykalo ${ }^{2, *}$ \\ ${ }^{1}$ Department of Cereal Crops Breeding, the V. M. Remeslo Myronivka Institute of Wheat of National Academy of Agrarian Sciences of \\ Ukraine, Tsentralne, Ukraine \\ ${ }^{2}$ Department of Biotechnology, Genetics and Physiology, the V. M. Remeslo Myronivka Institute of Wheat of National Academy of Agrarian \\ Sciences of Ukraine, Tsentralne, Ukraine
}

\author{
Email address: \\ mvis.mip@gmail.com (S. Pykalo) \\ ${ }^{*}$ Corresponding author
}

\section{To cite this article:}

Oleksandr Demydov, Svitlana Khomenko, Maryna Fedorenko, Yevhenii Kuzmenko, Serhii Pykalo. Stability and Plasticity of Collection Samples of Durum Spring Wheat in the Forest-Steppe Conditions of Ukraine. American Journal of Agriculture and Forestry.

Vol. 9, No. 2, 2021, pp. 83-88. doi: 10.11648/j.ajaf.20210902.16

Received: February 25, 2021; Accepted: March 11, 2021; Published: March 22, 2021

\begin{abstract}
When working with collection material, one of the main problems is the study of most of the samples in a cycle of three years and the annual partial renewal of the set under study. Therefore, only a part of the varieties can be directly compared with each other in terms of ecological stability, and the main grouping has to be carried out by comparing the behavior of samples with standard varieties under conditions of different years. Even well-studied varieties are not always suitable for such comparisons. When selecting the starting material for breeding, it is important not only to find forms with a high level of manifestation of quantitative traits, but also to minimize this level under unfavorable conditions for plant growth and development. The purpose of our research was to determine the stability and plasticity of collection samples of spring durum wheat of various ecological and geographical origins. Over the years of the research, the yield averaged $330.3 \mathrm{~g} / \mathrm{m}^{2}$ and varied from $434.3 \mathrm{~g} / \mathrm{m}^{2}(\max )$ in 2015 to $188.5 \mathrm{~g} / \mathrm{m}^{2}(\mathrm{~min})$ in 2018 . This indicates that the genotype and contrast weather conditions of the years significantly affect the yield of collection samples of spring durum wheat. Stable and plastic collection samples of spring durum wheat were identified for yield: 193 THKNEE 8 (Mexico) $\left(b_{i}=1.02, \mathrm{~S}^{2} \mathrm{~d}_{\mathrm{i}}=0.11\right.$ ), ARN AAZ-1.040 YRC-4M (Mexico) $\left(b_{i}=1.35, S^{2} d_{i}=0.12\right)$, SHAG $21 /$ CASCA (Mexico) $\left(b_{i}=1.07, \mathrm{~S}^{2} d_{i}=0.23\right)$, Hordeiforme 13-07 (Ukraine) ( $b_{i}=2.11$, $\left.\mathrm{S}^{2} \mathrm{~d}_{\mathrm{i}}=0.31\right)$. According to the results of our research, it was found that the highest grain weight per spike $(1.90 \mathrm{~g})$ was in the sample Voronezhskaya 11 (Russia), and the lowest value was in the sample Damsinskaya yantarnaya (Kazakhstan) (1.57 g). Among the plastic and stable collection samples by the grain weight per spike, the following samples were distinguished: DUN / MUSK $1\left(b_{i}=3.45 ; \mathrm{S}^{2} \mathrm{~d}_{\mathrm{i}}=0.07\right)$, SHAG 9 / BBUTO / $7\left(\mathrm{~b}_{\mathrm{i}}=1.61 ; \mathrm{S}^{2} \mathrm{~d}_{\mathrm{i}}=0,05\right)$, CASM $3 / / \mathrm{SRN} 3$ ASAIH $15\left(\mathrm{~b}_{\mathrm{i}}=1.47 ; \mathrm{S}^{2} \mathrm{~d}_{\mathrm{i}}=\right.$ 0.00), GREEN / SOMO ( $\left.b_{i}=1.35 ; \mathrm{S}^{2} \mathrm{~d}_{\mathrm{i}}=0.01\right)\left(\right.$ Mexico), Lilek (Russia) $\left(\mathrm{b}_{\mathrm{i}}=0.92, \mathrm{~S}^{2} \mathrm{~d}_{\mathrm{i}}=0.03\right)$, MAGH 72 FUTO ALG 86 (Mexico) $\left(b_{\mathrm{i}}=0.75, \mathrm{~S}^{2} \mathrm{~d}_{\mathrm{i}}=0.01\right)$, YAZI 13 (Mexico) $\left(\mathrm{b}_{\mathrm{i}}=0.12, \mathrm{~S}^{2} \mathrm{~d}_{\mathrm{i}}=0.07\right)$.
\end{abstract}

Keywords: Spring Durum Wheat, Collection Samples, Stability Variance, Plasticity, Yield, Grain Weight per Spike

\section{Introduction}

When selecting the starting material for breeding, it is important not only to find forms with a high level of manifestation of quantitative traits, but also to minimize this level under unfavorable conditions for plant growth and development [1].
The main task of breeding grain crops is to increase the adaptive potential of newly created varieties while maintaining the achieved yield level [2]. The adaptability of the variety is one of its most important properties; therefore, considerable attention is paid to this trait in breeding programs in most countries of the world [3, 4]. The experience of domestic and world breeding testifies to the 
fact that in the process of creating wheat varieties, the availability of starting material is of decisive importance, which combines productivity with adaptive traits $[5,6]$. Thus, the issues of ecological adaptability and plasticity of individual genotypes occupy an important place in the development of selection $[7,8]$.

Determination of the optimal type of plants capable of stably realizing their potential and at the same time adequately responding to changes in growing conditions constantly attracts the attention of scientists [9-11].

The method for assessing the ecological plasticity and variance of its stability of varieties based on the analysis of variance and regression makes it possible to assess their reactions under different growing conditions [12, 13].

The study of breeding material in the years that are different in hydrothermal conditions provides information on the characteristics of the reaction of genotypes to changing environmental conditions [14-16]. The concepts of "stability" and "plasticity" are interpreted differently in the scientific literature, which complicates the assessment of these parameters and their use in selection [17-19].

The ecological plasticity of a selection trait of a sample is its average response to changes in environmental conditions. The stability variance of the selection trait of the sample is the deviation of empirical data in specific environmental conditions from the ecological plasticity of the selection trait, that is, from the average response to a change in growing conditions. As a factor "conditions" can be years of research, zone, fertilizer doses, plant density, sowing dates, etc. [20].

The regression coefficient $\left(b_{i}\right)$ characterizes the average reaction of the selection trait of the sample to changes in environmental conditions and shows the plasticity of the selection trait, which makes it possible to predict the change in the trait studied in different years.

The stability variance $\left(\mathrm{S}^{2} \mathrm{~d}_{\mathrm{i}}\right)$ indicates how reliably the selection trait of a sample corresponds to the plasticity estimated by the regression coefficient $\left(b_{i}\right)$. The stability of the manifestation of the trait level is expressed at low coefficients of regression (plasticity) and low fluctuations in their stability variance.

The high sensitivity of individual varieties to unfavorable growing conditions often narrows the area and limits their overall distribution. Based on the testing of spring durum wheat varieties in different growing regions, it is possible to predict a genetically determined degree of yield stability (adaptability to growing conditions) [21].

Since the weather conditions become more and more changeable every year, the creation of new varieties with a high level of productivity, regardless of growing conditions, remains relevant up to now. The application of ecological plasticity and stability is widely used in such agricultural crops as winter bread wheat [22], spring bread and hard wheat [23, 24], winter and spring barley [25-28], soybean [29], winter triticale [30], oats [31, 32], corn [33], bean [34], etc. The stability of the breeding trait of sample is the deviation of empirical data in each environmental condition from the ecological plasticity of the breeding trait, that is, from average response to changing growing conditions.

The aim of the study was to determine the stability and plasticity of collection samples of spring durum wheat of various ecological and geographical origins.

\section{Materials and Methods}

The research was carried out during 2015-2018 at the Spring Wheat Breeding Laboratory of the V. M. Remeslo Myronivka Institute of Wheat of National Academy of Agrarian Sciences of Ukraine.

There were studied 104 collection samples of different ecological and geographical origin. The collection samples of spring durum wheat originate from 6 countries and belong to five varieties (var. hordeiforme, var. leucurum, var. leucomelan, var. melanopus, var. valenciale). Most of them were from Mexico 74 (71.2\%), the others were from Ukraine 12 (11.5\%), Kazakhstan 9 (8.7\%), Russia 5 (4.8\%), Canada 3 $(2.9 \%)$ and France $1(0.9 \%)$.

Sowing was carried out in optimal terms on the experimental fields of breeding crop rotation using the SKS-6-10 seeder in four replications. The accounting area of the plot is $1 \mathrm{~m}^{2}$. The standard was the variety Spadshchyna which was sown every 25 samples. Stability and plasticity parameters were determined by the method of Eberhart, Russell [35]. Statistical indices were calculated according to Dospekhov [36].

\section{Results}

During period of the study (2015-2018), the weather conditions differed from the average annual indicators in terms of temperature, amount of precipitation and their distribution by months.

The hydrothermal coefficient (HTC) proposed by Selyaninov [37] is used for comprehensive characterization of the area's moisture content and its temperature regime. The period from sowing to germination was characterized by excessively humid conditions in 2015 (HTC $=4.40)$, optimal moisture conditions in 2017 ( $\mathrm{HTC}=1.27)$, dry conditions in $2016(\mathrm{HTC}=0.90)$, very dry conditions in $2018(\mathrm{HTC}=0.12)$. The period from germination to booting was characterized by optimal moisture conditions in 2015, 2016, 2017, and 2018 ( $\mathrm{HTC}=1.16 ; 1.10 ; 1.43 ; 1.07$, respectively). The period from booting to heading was characterized by excessive moisture in 2016 and 2018 (HTC $=2.20$ and 2.35, respectively) and optimal conditions in 2015 and 2017 (HTC $=1.10$ and 1.05, respectively).

Therefore, this gave us the opportunity to evaluate collection samples of spring durum wheat in terms of adaptability and to identify the best genotypes.

Over the years of the research, the yield averaged 330.3 $\mathrm{g} / \mathrm{m}^{2}$ and varied from $434.3 \mathrm{~g} \mathrm{~m}^{2}$ (max) in 2015 to $188.5 \mathrm{~g} / \mathrm{m}^{2}$ (min) in 2018. This indicates that the genotype and contrast weather conditions of the studied years significantly affect the yield of collection samples of spring durum wheat.

The best collection samples of spring durum wheat with 
high regression coefficient $b_{i}$ and the most response to changes in environmental conditions in terms of yield are presented (Table 1): Hordeiforme 13-07 $\left(b_{i}=2.11\right)$, Kharkivska $27\left(b_{i}=1.97\right)$ (Ukraine), NDER2 RASCON 22-1Y $\left(b_{i}=1.61\right)$, Hordeiforme 13-08 $\left(b_{i}=1.51\right)$ (Ukraine),
Lilek (Russia) $\left(b_{i}=1.47\right)$, YAZI 13 (Mexico) $\left(b_{i}=1.45\right)$, SHAG 8.2B-OYRC $\left(b_{i}=1.40\right)$, ARN AAZ-1.040 YRC-4M $\left(b_{i}=1.35\right)$, COTE / ASAISA / FILLO $3\left(b_{i}=1.30\right)$, Adomar 7 $\left(b_{i}=1.29\right)$.

Table 1. Plasticity coefficients and stability variances by yield of collection samples of spring durum wheat (2015-2018).

\begin{tabular}{|c|c|c|c|c|c|c|c|c|}
\hline \multirow{2}{*}{ Variety } & \multirow{2}{*}{ Origin } & \multicolumn{4}{|c|}{ Yield, $\mathrm{g} / \mathrm{m}^{2}$} & \multirow{2}{*}{ Mean, $\mathbf{x}_{\mathbf{i}}$} & \multirow{2}{*}{$\mathbf{b}_{\mathbf{i}}$} & \multirow{2}{*}{$\mathbf{S}^{2} \mathbf{d}_{\mathrm{i}}$} \\
\hline & & 2015 & 2016 & 2017 & 2018 & & & \\
\hline Spadshchyna (standard) & Ukraine & 494.3 & 411.0 & 291.0 & 181.0 & 344.3 & 1.15 & 0.11 \\
\hline Hordeiforme 13-08 & Ukraine & 634.3 & 464.0 & 445.0 & 157.0 & 425.1 & 1.51 & 1.19 \\
\hline Hordeiforme 13-07 & Ukraine & 698.6 & 556.0 & 308.0 & 135.0 & 424.4 & 2.11 & 0.31 \\
\hline Lilek & Russia & 557.1 & 620.0 & 206.0 & 293.0 & 419.0 & 1.47 & 1.57 \\
\hline ARN AAZ-1.040 YRC-4M & Mexico & 575.7 & 536.0 & 311.0 & 252.0 & 418.7 & 1.35 & 0.12 \\
\hline Kharkivska 27 & Ukraine & 654.3 & 577.0 & 240.0 & 180.0 & 412.8 & 1.97 & 0.45 \\
\hline COTE / ASAISA // FILLO 3 & Mexico & 457.3 & 598.1 & 378.6 & 194.0 & 407.0 & 1.30 & 0.76 \\
\hline Omskiy izumrud & Russia & 410.0 & 559,0 & 363,0 & 268,0 & 400.0 & 0.86 & 0.67 \\
\hline Adomar 7 & Mexico & 605.7 & 458.0 & 270.0 & 258.0 & 397.9 & 1.29 & 0.71 \\
\hline MUSK DUKEN & Mexico & 408.6 & 354.0 & 507.0 & $310 ., 0$ & 394.9 & 0.10 & 1.06 \\
\hline 143 KIRKI 9 & Mexico & 457.1 & 486.0 & 500.0 & 134.0 & 394.3 & 1.12 & 1.97 \\
\hline 193 THKNEE 8 & Mexico & 517.1 & 445.0 & 359.0 & 231.0 & 388.0 & 1.02 & 0.11 \\
\hline Bezenchukskaya 105 & Russia & 430.0 & 561.0 & 278.0 & 280.0 & 387.3 & 0.98 & 0.79 \\
\hline Neodur & France & 477.1 & 433.0 & 410.0 & 228.0 & 387.0 & 0.84 & 0.33 \\
\hline NDER2 RASCON 22-1Y & Mexico & 671.4 & 393.0 & 295.0 & 165.0 & 381.1 & 1.61 & 1.61 \\
\hline SHAG 8.2B-OYRC & Mexico & 592.8 & 444.0 & 264.0 & 211.0 & 378.0 & 1.40 & 0.55 \\
\hline SHAG 21 / CASCA & Mexico & 441.4 & 521.0 & 320.0 & 224.0 & 376.6 & 1.07 & 0.23 \\
\hline YAZI 13 & Mexico & 446.3 & 587.6 & 298.4 & 164.0 & 374.1 & 1.45 & 0.68 \\
\hline 211 TIANES & Mexico & 512.8 & 377.0 & 351.0 & 250.0 & 372.7 & 0.81 & 0.40 \\
\hline SHAG 9 / BBUTO / 7 & Mexico & 455.7 & 424.0 & 398.0 & 213.0 & 372.7 & 0.84 & 0.34 \\
\hline Mean $x j^{*}$ & - & 434.3 & 418.6 & 280.0 & 188.5 & 330.3 & - & - \\
\hline environmental index $\mathrm{lj}^{* *}$ & - & 103.9 & 88.2 & -50.3 & -141.8 & - & - & - \\
\hline $\mathrm{LSD}_{05}$ & - & 3.53 & 3.36 & 2.79 & 2.28 & - & - & - \\
\hline
\end{tabular}

* $\mathrm{xj}$ is average for 104 collection samples; **lj is the difference between the average yield of all varieties for the year conditions to the total average yield for all experiments; LSD is the least significant difference

The regression coefficient close to 1.0 was a feature for the following samples: Bezenchukskaya $105\left(b_{i}=0.98\right)$, Omskiy izumrud $\left(b_{i}=0.86\right)$ (Russia), Neodur (France) $\left(b_{i}=0.84\right)$, SHAG 9 / BBUTO / $7\left(b_{i}=0.84\right), 211$ TIANES $\left(b_{i}=0.81\right)$ (Mexico). Such samples showed the best results under stress (contrast) growing conditions.

Stabile and plastic collection samples of spring durum wheat were identified according to yield: 193 THKNEE 8 (Mexico) $\left(b_{i}=1.02, \mathrm{~S}^{2} \mathrm{~d}_{\mathrm{i}}=0.11\right)$, ARN AAZ-1.040 YRC-4M (Mexico) $\left(b_{i}=1.35, \mathrm{~S}^{2} d_{i}=0.12\right)$, SHAG $21 /$ CASCA (Mexico) $\left(b_{i}=1.07, \mathrm{~S}^{2} \mathrm{~d}_{\mathrm{i}}=0.23\right)$, Hordeiforme 13-07 (Ukraine) $\left(\mathrm{b}_{\mathrm{i}}=\right.$ $\left.2.11, \mathrm{~S}^{2} \mathrm{~d}_{\mathrm{i}}=0.31\right)$. These collection samples can be used in subsequent breeding programs for yielding capacity.

An important element of productivity of durum spring wheat is grain weight per spike which depends on a number of factors: spike length, grain number per spike, grain size, as well as on growing conditions.

According to the results of our research, it was found that the highest $(1.90 \mathrm{~g})$ grain weight per spike was noted in the sample Voronezhskaya 11 (Russia), and the least $(1.57 \mathrm{~g})$ it was in the sample Damsinskaya yantarnaya (Kazakhstan) (Table 2).

According to the stability of the trait grain weight per spike, high indicators of the regression coefficient $\left(b_{i}\right)$ and the most response to changes in environmental conditions were revealed in the following collection samples: ETH-LRBRA-2-28 / ALTAR 84 // (Mexico) $\left(\mathrm{b}_{\mathrm{i}}=4.84\right)$, DUN / MUSK 1 (Mexico) $\left(b_{i}=3.45\right)$, Seymour (Kazakhstan) $\left(b_{i}=\right.$ 2.94), Tera (Ukraine) $\left(b_{i}=2.27\right)$, SHAG $9 /$ BBUTO / 7 (Mexico) $\left(b_{i}=1.61\right)$, Ertol (Kazakhstan) $\left(b_{i}=1.57\right)$, S 15 FOCHA 1.030M-1Y (Mexico) (bi = 1.49), Damsinskaya yantarnaya (Kazakhstan) $\left(b_{i}=1.49\right)$, CASM $3 / /$ SRN 3 ASAIH 15 (Mexico) $\left(b_{i}=1.47\right)$, Voronezhskaya 11 (Russia) $\left(b_{i}=1.45\right)$, Kharkivska 27 (Ukraine) $\left(b_{i}=1.43\right)$, GREEN / SOMO (Mexico) $\left(b_{i}=1.35\right)$.

The collection samples were identified with regression coefficient being close to 1.0 under fluctuating weather conditions: Lilek (Russia), MAGH 72 FUTO ALG 86 (Mexico).

According to the stability variance $\left(\mathrm{S}^{2} \mathrm{~d}_{\mathrm{i}}\right)$, the following samples were distinguished among the plastic and stable collection samples: DUN / MUSK $1\left(b_{i}=3.45 ;=0.07\right)$, SHAG 9 / BBUTO / $7\left(b_{i}=1.61 ; \mathrm{S}^{2} \mathrm{~d}_{\mathrm{i}}=0.05\right), \mathrm{CASM} 3 / / \mathrm{SRN} 3$ ASAIH $15\left(b_{i}=1.47 ; \mathrm{S}^{2} d_{i}=0.00\right)$, GREEN / SOMO $\left(b_{i}=1.35\right.$; $\left.\mathrm{S}^{2} \mathrm{~d}_{\mathrm{i}}=0.01\right)$ (Mexico), Lilek (Russia) $\left(\mathrm{b}_{\mathrm{i}}=0.92, \mathrm{~S}^{2} \mathrm{~d}_{\mathrm{i}}=0.03\right)$, MAGH 72 FUTO ALG 86 (Mexico) $\left(b_{i}=0.75, \mathrm{~S}^{2} \mathrm{~d}_{\mathrm{i}}=0.01\right)$, 
YAZI 13 (Mexico) $\left(b_{i}=0.12, \mathrm{~S}^{2} d_{i}=0.07\right)$.

Table 2. Plasticity coefficients and stability variances of collection samples of spring durum wheat by grain weight per spike (2015-2018).

\begin{tabular}{|c|c|c|c|c|c|c|c|c|}
\hline \multirow{2}{*}{ Variety } & \multirow{2}{*}{ Origin } & \multicolumn{4}{|c|}{ Grain weight per spike, $\mathrm{g}$} & \multirow{2}{*}{ Mean, $\mathbf{x}_{\mathbf{i}}$} & \multirow{2}{*}{$\mathbf{b}_{\mathbf{i}}$} & \multirow{2}{*}{$\mathbf{S}^{2} \mathbf{d}_{\mathrm{i}}$} \\
\hline & & 2015 & 2016 & 2017 & 2018 & & & \\
\hline Spadshchyna (standard) & Ukraine & 1.50 & 2.17 & 0.98 & 1,97 & 1.65 & 1.13 & 0.70 \\
\hline Voronezhskaya 11 & Russia & 1.96 & 2.58 & 1.46 & 1.62 & 1.90 & 1.45 & 0.56 \\
\hline GREEN / SOMO & Mexico & 2.19 & 1.81 & 1.68 & 1.86 & 189 & 1.35 & 0.01 \\
\hline 193 THK NTF 8 & Mexico & 1.96 & 2.23 & 1.54 & 1.71 & 1.86 & 1.16 & 0.17 \\
\hline ETH-LRBRA-2-28 / ALTA 84 // & Mexico & 2.99 & 1.72 & 1.28 & 1.42 & 1.85 & 4.84 & 0.17 \\
\hline S 15 FOCHA 1.030M-1Y & Mexico & 2.30 & 1.39 & 1.73 & 1.92 & 1.84 & 1.49 & 0.27 \\
\hline Seymur & Kazakhstan & 2.53 & 1.70 & 1.48 & 1.63 & 1.84 & 2.94 & 0.07 \\
\hline CASM 3 // SRN 3ASAIH 15 & Mexico & 2.07 & 1.80 & 1.54 & 1.70 & 1.78 & 1.47 & 0.00 \\
\hline YAZI 13 & Mexico & 1.84 & 1.55 & 1.76 & 1.95 & 1.77 & 0.12 & 0.07 \\
\hline 143 KIRKI 9 & Mexico & 1.50 & 1.44 & 1.97 & 2.18 & 1.77 & -1.51 & 0.17 \\
\hline LABUD SRN 2 & Mexico & 1.61 & 1.60 & 1.77 & 1.95 & 1.73 & -0.55 & 0.04 \\
\hline SHAG 21 / CASCA & Mexico & 1.73 & 1.58 & 1.71 & 1.89 & 1.72 & -0.04 & 0.03 \\
\hline CN 16 // BER / SB 15 (3) POLEMA 4523 & Mexico & 1.50 & 1.33 & 1.93 & 2.13 & 1.72 & -1.39 & 0.22 \\
\hline Tera & Ukraine & 2.19 & 1.70 & 1.37 & 1.52 & 1.70 & 2.27 & 0.01 \\
\hline 193 THKNEE 8 & Mexico & 1.61 & 1.46 & 1.74 & 1.92 & 1.68 & -0.48 & 0.07 \\
\hline RU / MINIMUS & Mexico & 1.61 & 1.52 & 1.70 & 1.89 & 1.68 & -0.37 & 0.04 \\
\hline MAGH 72 FUTO ALG 86 & Mexico & 1.84 & 1.61 & 1.55 & 1.72 & 1.68 & 0.75 & 0.01 \\
\hline 030M- Y-0M & Mexico & 1.27 & 1.55 & 1.83 & 2.02 & 1.67 & -1.72 & 0.08 \\
\hline SHAG 9 / BBUTO / 7 & Mexico & 2.07 & 1.48 & 1.48 & 1.63 & 1.67 & 1.61 & 0.05 \\
\hline Neodur & France & 1.84 & 1.71 & 1.45 & 1.60 & 1.65 & 1.07 & 0.00 \\
\hline Ertol & Kazakhstan & 1.84 & 1.98 & 1.29 & 1.43 & 1.63 & 1.57 & 0.14 \\
\hline DUN / MUSK 1 & Mexico & 2.42 & 1.54 & 1.19 & 1.32 & 1.62 & 3.45 & 0.07 \\
\hline $\mathrm{SBH}(5) \mathrm{BRCH} / 134 * 5-6$ & Mexico & 1.50 & 1.30 & 1.74 & 1.92 & 1.61 & -0.83 & 0.14 \\
\hline MUSK DUKEN & Mexico & 1.38 & 2.04 & 1.44 & 1.59 & 1.61 & -0.18 & 0.26 \\
\hline Lilek & Russia & 1,84 & 1,47 & 1,49 & 1,65 & 1,61 & 0,92 & 0,03 \\
\hline Kharkivska 27 & Ukraine & 1.73 & 2.00 & 1.23 & 1.36 & 1.58 & 1.43 & 0.21 \\
\hline Toma & Kazakhstan & 1.44 & 2.15 & 1.29 & 1.43 & 1.58 & 0.46 & 0.43 \\
\hline Damsinskaya yantarnaya & Kazakhstan & 1.84 & 1.70 & 1.31 & 1.45 & 1.57 & 1.49 & 0.02 \\
\hline Mean xj* & & 1.70 & 1.51 & 1.33 & 1.47 & 1.50 & & \\
\hline environmental index $\mathrm{lj}^{* * *}$ & & 0.20 & 0.01 & -0.17 & 0.03 & & & \\
\hline $\mathrm{LSD}_{05}$ & & 0.14 & 0.16 & 0.11 & 0.31 & & & \\
\hline
\end{tabular}

${ }^{*} \mathrm{xj}$ is average for 104 collection samples; $* * \mathrm{lj}$ is the difference between the average yield of all varieties for the year conditions to the total average yield for all experiments; LSD is the least significant difference

\section{Conclusions}

As a result of the studies, it was found that stability and plasticity depend on the genotype. Stable and plastic collection samples of spring durum wheat were identified based on yield: 193 THKNEE 8 (Mexico) $\left(b_{i}=1.02, \mathrm{~S}^{2} \mathrm{~d}_{\mathrm{i}}=\right.$ 0.11), ARN AAZ-1.040 YRC-4M (Mexico) $\left(\mathrm{b}_{\mathrm{i}}=1.35, \mathrm{~S}^{2} \mathrm{~d}_{\mathrm{i}}=\right.$ $0.12)$, SHAG $21 /$ CASCA (Mexico) $\left(b_{i}=1.07, \mathrm{~S}^{2} \mathrm{~d}_{\mathrm{i}}=0.23\right)$, Hordeiforme 13-07 (Ukraine) $\left(b_{i}=2.11, \mathrm{~S}^{2} \mathrm{~d}_{\mathrm{i}}=0.31\right)$. It was found that the high $(1.90 \mathrm{~g})$ grain weight per spike was in the sample Voronezhskaya 11 (Russia) and the lowest value (1.57 g) was in the sample Damsinskaya yantarnaya (Kazakhstan). Among the plastic and stable collection samples by the grain weight per spike were the following samples were identified: DUN / MUSK $1\left(b_{i}=3.45 ; \mathrm{S}^{2} d_{i}=0.07\right)$, SHAG 9 / BBUTO / 7 $\left(b_{i}=1.61 ; \mathrm{S}^{2} d_{i}=0.05\right)$, CASM $3 / /$ SRN 3 ASAIH $15\left(b_{i}=\right.$ 1.47; $\left.\mathrm{S}^{2} \mathrm{~d}_{\mathrm{i}}=0.00\right)$, GREEN / SOMO $\left(\mathrm{b}_{\mathrm{i}}=1.35 ; \mathrm{S}^{2} \mathrm{~d}_{\mathrm{i}}=0.01\right)$ (Mexico), Lilek (Russia) $\left(b_{i}=0.92, \mathrm{~S}^{2} \mathrm{~d}_{\mathrm{i}}=0.03\right.$ ), MAGH 72 FUTO ALG 86 (Mexico) $\left(b_{i}=0.75, \mathrm{~S}^{2} \mathrm{~d}_{\mathrm{i}}=0.01\right)$, YAZI 13 (Mexico) $\left(b_{\mathrm{i}}=0.12, \mathrm{~S}^{2} \mathrm{~d}_{\mathrm{i}}=0.07\right)$.

\section{References}

[1] Padalka, O. I., Muzafarova, V. A., Riabchun, V. K., Petukhova, I. A., \& Bohuslavskyi, R. L. (2016) Spring durum wheat trait collection by a set of valuable economic features a source of starting material for breeding. Plant Genetic Resources 19: 48-57.

[2] Studnicki M., Wijata M., Sobczyński G., Samborski S., \& Rozbicki J. (2018) Assessing grain yield and quality traits stability of spring wheat cultivars at different crop management levels. Cereal Res Commun 46 (1): 180-190. doi: 10.1556/0806.45.2017.066.

[3] Postovalov, A., Sukhanova, S., Plotnikov A., Sazhina, S., \& Sozinov, A. (2020) Formation of highly productive agrophytocenoses of peas and spring rapeseed in Trans-Urals. KnE Life Sci 5 (1): 475-481. doi: 10.18502/kls.v5i1.6109.

[4] Suneja, Y., Gupta, A. K., \& Bains, N. S. (2019) Stress adaptive plasticity: Aegilops tauschii and Triticum dicoccoides as potential donors of drought associated morpho-physiological traits in wheat. Front Plant Sci 10: 211. doi: $10.3389 /$ fpls.2019.00211. 
[5] Anuarbek, S., Abugalieva, S., Pecchioni, N, Laidò, G., Maccaferri, M., Tuberosa, R., \& Turuspekov, Y. (2020) Quantitative trait loci for agronomic traits in tetraploid wheat for enhancing grain yield in Kazakhstan environments. PLoS ONE 15 (6): e0234863. doi: 10.1371/journal.pone.0234863.

[6] Bleidere, M., Grunte, I., \& Legzdina, L. (2020) Performance and stability of agronomic and grain quality traits of Latvian spring barley varieties. Proc Latvian Acad Sci. Section B 74 (4): 270-279. doi: 10.2478/prolas-2020-0042.

[7] Ghaedrahmati, M., Hossein Pour, T., \& Ahmadi, A. (2017) Study of grain yield stability of durum wheat genotypes using AMMI. J Crop Breed 9 (23): 67-75.

[8] Mareniuk, A. B. (2014) Plasticity and stability of quantitative traits of collection spring barley variety samples under the conditions of increased soil acidity. Plant Breeding and Seed Production 106: 77-82 (UA).

[9] Arjona, J. M., Villegas, D., Ammar, K., Dreisigacker, S., Alfaro, C., \& Royo, C. (2020) The effect of photoperiod genes and flowering time on yield and yield stability in durum wheat. Plants 9 (12): 1723. doi: 10.3390/plants9121723.

[10] Hafsi, M., Hadji, A., Semcheddine, N., Rouabhi, A., \& Maamri, K. (2018) Stability value of carbon isotope discrimination tool for durum wheat selection in semi-arid condition. Agri Res \& Tech: Open Access J 18 (2): 556051. doi: 10.19080/ARTOAJ.2018.18.556051.

[11] Mohammadi R. (2014) Phenotypic plasticity of yield and related traits in rainfed durum wheat The Journal of Agricultural Science, Volume 152, Issue 6, December, pp. 873 - 884 doi: https://doi.org/10.1017/S0021859613000580.

[12] Bányai, J., Kiss, T., Gizaw, S. A., Mayer, M., Spitkó, T., Tóth, V., Kuti, C., Mészáros, K., Láng, L., Karsai, I., \& Vida, G. (2020) Identification of superior spring durum wheat genotypes under irrigated and rain-fed conditions. Cereal Res Commun 48: 355-364. https://doi.org/10.1007/s42976-020-00034-z.

[13] Hassan, M. S., Mohamed, G. I. A., \& El-Said, R. A. R. (2013) Stability Analysis for Grain Yield and its Components of Some Durum Wheat Genotypes (Triticum durum L.) Under Different Environments. Asian Journal of Crop Science 5: 179-189. https://doi.org/10.3923/ajcs.2013.179.189.

[14] Mazzucotelli, E., Sciara, G., Mastrangelo, A., Desiderio, F., $\mathrm{Xu}$, SS., Faris, J., Hayden, M. J., Tricker, P. J., Ozkan, H., Echenique, V., Steffenson, B. J., Knox, R., Niane, A. A., Udupa, S. M., Longin, F. C. H., Marone, D., Petruzzino, G., Corneti, S., Ormanbekova, D., Pozniak, C., Roncallo, P. F., Mather, D., Able, J. A., Amri, A., Braun, H., Ammar, K., Baum, M., Cattivelli, L., Maccaferri, M., Tuberosa, R., \& Bassi, F. M. (2020) The Global Durum Wheat Panel (GDP): An International Platform to Identify and Exchange Beneficial Alleles. Front Plant Sci 11: 569905. https://doi.org/10.3389/fpls.2020.569905.

[15] Adjabi, A., Bouzerzour, H., \& Benmahammed, A. (2014) Stability Analysis of Durum Wheat (Triticum durum Desf.) Grain Yield. Journal of Agronomy 13: 131-139. https://doi.org/10.3923/ja.2014.131.139.

[16] Schauberger, B., Ben-Ari, T., Makowski, D. Kato, T., Kato, H., \& Ciais, Ph. (2018) Yield trends, variability and stagnation analysis of major crops in France over more than a century. $\begin{array}{llll}\text { Sci Rep } & 8, & 16865 .\end{array}$ https://doi.org/10.1038/s41598-018-35351-1.
[17] Mekonnen, M., Sharie, G., Bayable, M., Teshager, A., Abebe, E., Ferede, M., Fentie, D., Wale, S., Tay, Y., Getaneh, D., Ayaleneh, Z., \& Malefia, A. (2020) Participatory variety selection and stability analysis of Durum wheat varieties (Triticum durum Desf.) in northwest Amhara. Cogent Food \&

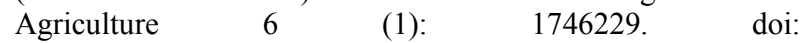
$10.1080 / 23311932.2020 .1746229$.

[18] Beral, A., Rincent, R., Le Gouis, J., Girousse, C., \& Allard, V. (2020) Wheat individual grain-size variance originates from crop development and from specific genetic determinism. $\begin{array}{lllll}\text { PLoS } & \text { ONE } & 15 & \text { (3): } & \text { e230689. }\end{array}$ https://doi.org/10.1371/journal.pone.0230689.

[19] Oostra, V., Saastamoinen, M., Zwaan, B. J. \& Wheat, C. W. (2018) Strong phenotypic plasticity limits potential for evolutionary responses to climate change. Nat Commun 9: 1005. https://doi.org/10.1038/s41467-018-03384-9.

[20] Chevin, L. M, Hoffmann, A. A. (2017) Evolution of phenotypic plasticity in extreme environments. Phil Trans R Soc B 372: 20160138. http://dx.doi.org/10.1098/rstb.2016.0138.

[21] Sanad, M. N. M. E., Campbell, K. G., \& Gill, K. S. (2016) Developmental program impacts phenological plasticity of spring wheat under drought. Bot Stud 57: 35. doi: 10.1186/s40529-016-0149-3.

[22] Kochmarskyi, V. S., Zamlila, N. P., Vologdina, G. B., Gumeniuk, O. V., \& Voloshchuk, S. I. (2016) Adaptability level of perspective lines of bread winter wheat in the conditions of Forest-steppe of Ukraine. Myronika Bulletin 2: 98-116 (UA). doi: 10.21498/2518-7910.0.2016.119549.

[23] Khomenko, S. O., Kochmarskyi, V. S., Fedorenko, I. V., \& Fedorenko, M. V. (2018) Stability and plasticity of collection samples of soft spring wheat in terms of productivity. Bulletin of Uman National University of Horticulture 1: 43-47 (UA). doi: 10.31395/2310-0478-2018-1-43-47.

[24] Khomenko, S. O., Kochmarskyi, V. S., Fedorenko, I. V., \& Fedorenko, M. V. (2020) Breeding value of spring durum wheat accessions for performance traits under environment of Ukrainian Forest-Steppe. Plant Varieties Studying and $\begin{array}{lllll}\text { Protection } & 16 & \text { (3): } 303-309 & \text { (UA). } & \text { doi: }\end{array}$ 10.21498/2518-1017.16.3.2020.214924.

[25] Hudzenko, V. M., Vasylkivskyi, S. P., \& Polishchuk, T. P. (2017) Performance and adaptability of spring barley accessions multi-years trials in the Central Forest-Steppe of Ukraine. Plant Genetic Resources 20: 31-43 (UA).

[26] Hudzenko, V. M., Polishchuk, T. P., Babii, O. O., \& Khudolii, L. V. (2018) Productivity and adaptability of Myronivka spring barley varieties of different breeding periods. Plant Varieties Studying and Protection 14 (2): 190-202 (UA). doi: 10.21498/2518-1017.14.2.2018.134766.

[27] Gudzenko, V. N. (2019) Statistical and graphical (GGE biplot) evaluation of the adaptive ability and stability of winter barley breeding lines. Vavilov Journal of Genetics and Breeding 23 (1): 110-118 (RU). doi: 10.18699/VJ19.469.

[28] Nikolaev, P. N., Popolzukhin, P. V., Aniskov, N. I., Yusova, O. A., \& Safonova, I. V. (2018) Evaluation of the adaptive properties of spring barley varieties according to their yield capacity in the environments of the Near-Irtysh area in Omsk province. Proc Appl Bot Genet Plant Breed 179 (2): 96-105 (RU). doi: 10.30901/2227-8834-2018-2-96-105. 
[29] Bilyavska, L. G.., Belyavskiy, Y. V., \& Diyanova, A. A. (2018) Estimation of environmental stability and plasticity of soybean varieties. Legumes and Groat Crops 4: 42-48 (RU). doi: 10.24411/2309-348X-2018-11048.

[30] Shchypak, H. V., Sviatchenko, S. I., \& Nepochatov, M. I. (2014) Evaluation of winter triticale variety samples by ecological plasticity and stability of basic productivity traits Bulletin of the Center for Science Provision of Agribusiness in the Kharkiv region 16: 247-256 (UA).

[31] Marukhnyak A. Ya., Dats'ko A. O., Lisova Yu. A., \& Marukhnyak, H. I. (2017) Plasticity and stability of quantitative signs of productivity of oat samples. Foothill and Mountain Agriculture and Stockbreeding. 61: 80-90 (UA).

[32] Buniak, O. I. (2016) Ecological stability and plasticity of naked oat varieties in the Northern Forest-Steppe of Ukraine. Myronivka Bulletin 2: 25-39 (UA).

[33] Taran, V. G., Kalenska, S. M., Novytska, N. V., \& Daniliv, P. O. (2018) Stability and plasticity of corn hybrids in depending on fertilizing system and density of plant stand in the right-bank forest-steppe of Ukraine. Bioresources and Nature Management. Agronomy 10 (3-4): 147-156 (UA). https://doi.org/10.31548/bio2018.03.019.

[34] Mazur, V. A., Branitsky, Y. Y., \& Mazur, O. V. (2020) Selection value and adaptability of common bean varieties in the conditions of Uladovo-Lyulinetska research and selection station of Institute of Bioenergy Crops and Sugar Beets NAASU. Agriculture and Forestry 19: 5-14 (UA). doi: 10.37128 / 2707-5826-2020-4-1.

[35] Eberhart, S. A., \& Russell, W. A. (1966) Stability parameters for comparing varieties. Crop Sci 6 (1): 36-40.

[36] Dospekhov, B. A. (1985) Methods of field experiment (with the basics of statistical processing of research results). Moscow: Agropromizdat (RU).

[37] Selyaninov, G. T. (1937). Methods of agricultural characteristics of climate. In World Agroclimatic Reference Book (pp. 5-29). Moscow: Gidrometeoizdat (RU). 